\title{
Site-specific nitrogen balances based on spatially variable soil and plant properties
}

\author{
Martin Mittermayer ${ }^{1}$ D $\cdot$ August Gilg $^{2} \cdot$ Franz-Xaver Maidl $^{1} \cdot$ Ludwig Nätscher $^{1}$. \\ Kurt-Jürgen Hülsbergen ${ }^{1}$
}

Received: 2 April 2020 / Accepted: 15 January 2021 / Published online: 5 February 2021

(C) The Author(s) 2021

\begin{abstract}
In this study, site-specific $\mathrm{N}$ balances were calculated for a 13.1 ha heterogeneous field. Yields and $\mathrm{N}$ uptake as input data for $\mathrm{N}$ balances were determined with data from a combine harvester, reflectance measurements from satellites and tractor-mounted sensors. The correlations between the measured grain yields and yields determined by digital methods were moderate. The calculated values for the $\mathrm{N}$ surpluses had a wide range within the field. Nitrogen surpluses were calculated from -76.4 to $91.3 \mathrm{~kg} \mathrm{ha}^{-1}$, with a mean of $24.0 \mathrm{~kg}$ $\mathrm{ha}^{-1}$. The use of different data sources and data collection methods had an impact on the results of $\mathrm{N}$ balancing. The results show the need for further optimization and improvement in the accuracy of digital methods. The factors influencing $\mathrm{N}$ uptake and $\mathrm{N}$ surplus were determined by analysing soil properties of georeferenced soil samples. Soil properties showed considerable spatial variation within the field. Soil organic carbon correlated very strongly with total nitrogen content $(r=0.97)$, moderately with $\mathrm{N}$ uptake (sensor, $r=0.60$ ) and negatively with $\mathrm{N}$ surplus (satellite, $r=-0.46$; sensor, $r=-0.56$; harvester, $r=-0.60)$. Nitrate content was analysed in soil cores $(0$ to $9 \mathrm{~m})$ taken in different yield zones, and compared with the calculated $\mathrm{N}$ surplus; there was a strong correlation between the measured nitrate content and calculated $\mathrm{N}$ surplus $(r=0.82)$. Site-specific $\mathrm{N}$ balancing can contribute to a more precise identification of the risk of nitrate losses and the development of targeted nitrate reduction strategies.
\end{abstract}

Keywords Spatial variation $\cdot$ Soil heterogeneity $\cdot$ Nitrogen surplus $\cdot$ Site-specific farming . Sensor data $\cdot \mathrm{N}$ balance

\section{Introduction}

\section{$\mathbf{N}$ balance and site-specific $\mathbf{N}$ fertilizer application}

Nitrogen $(\mathrm{N})$ surplus is one of the most important agri-environmental indicators (Salo and Turtola 2006; Sieling and Kage 2006; Sassenrath et al. 2013). It describes the

Martin Mittermayer

martin.mittermayer@tum.de

Extended author information available on the last page of the article 
potential loss of reactive $\mathrm{N}$ compounds $\left(\mathrm{NH}_{3}, \mathrm{~N}_{2} \mathrm{O}, \mathrm{NO}_{3}{ }^{-}\right)$at different system levels, e.g. field, crop rotation or farm (Hülsbergen 2003; McLellan et al. 2018). In Germany, $\mathrm{N}$ surpluses, at around $90 \mathrm{~kg} \mathrm{ha}^{-1} \mathrm{a}^{-1}$, have been much too large for years; this has led to $\mathrm{N}$ emissions that have negative environmental impacts and contribute to climate change (Isermann 1990; van der Ploeg et al. 1997; Küstermann et al. 2010; McLellan et al. 2018).

A promising approach for increasing $\mathrm{N}$ efficiency and reducing $\mathrm{N}$ surplus is site-specific, sensor-based $\mathrm{N}$ fertilizer application (Spicker 2016; Pahlmann et al. 2017); however, despite the increasing availability and performance of sensor-based $\mathrm{N}$ fertilizer application systems (Maidl et al. 2019), uniform fertilizer application is still common agricultural practice (Frogbrook and Oliver 2007; Stamatiadis et al. 2018).

\section{Variation in soil properties and their influence on $\mathbf{N}$ balance}

Many arable fields show spatial variation in yields and $\mathrm{N}$ uptake of crops because of differences in slope and topography (exposure) (Hatfield 2000; Godwin et al. 2003). Soil texture, available water capacity, $\mathrm{pH}$, humus and nutrient contents can vary considerably within a small area, even in fields that have been cultivated uniformly over many years (Hülsbergen 2003; López-Lozano et al. 2010; Servadio et al. 2017).

If $\mathrm{N}$ fertilizer is applied uniformly on heterogeneous fields this can mean that (a) the yield potential in the high-yield zones is not fully realised and/or $\mathrm{N}$ uptake of plants will exceed the N supply and reduce soil N stocks (Dalgaard et al. 2012), (b) large N surpluses and nitrate losses occur in the low yielding zones and $\mathrm{N}$ may also accumulate in the soil (Dalgaard et al. 2012; Hülsbergen et al. 2017). It can, therefore, also be assumed that $\mathrm{N}$ surpluses and losses vary in heterogeneous fields. Under these conditions, even if, on average, $\mathrm{N}$ inputs and $\mathrm{N}$ outputs are balanced $(\mathrm{N}$ surplus $=0)$, some parts of the field could have a large $\mathrm{N}$ surplus and therefore potential $\mathrm{N}$ losses, whereas there could be an $\mathrm{N}$ deficit in other parts of the field. Site-specific $\mathrm{N}$ balances enable $\mathrm{N}$ losses that negatively impact the environment to be quantified more precisely. There are only a few scientific studies on the spatial variation of $\mathrm{N}$ surpluses and potential nitrate losses.

\section{Technologies for determining georeferenced plant and soil variables}

A prerequisite for site-specific $\mathrm{N}$ fertilizer application and balancing is the availability of georeferenced plant and soil variables (e.g. crop yield, biomass $\mathrm{N}$ content, $\mathrm{N}$ uptake, soil nitrogen content). These data, which are used as input data in the $\mathrm{N}$ balance, can be collected using different technologies with different spatial resolutions, accuracy, costs and availability (Finger et al. 2019). For example, data from tractor-mounted multispectral reflection sensors (Maidl et al. 2019), satellite data (ESA 2018), drones with multispectral cameras (Maes and Steppe 2019) or data from combine harvesters with integrated yield recording (Bachmaier 2007) can be used to measure and calculate the biomass and $\mathrm{N}$ uptake of crop stands.

\section{Study aims}

This research explores the causes of the influence of small-scale variable soil parameters on yield and potential nitrogen losses. The aim is to identify under which conditions high 
$\mathrm{N}$ surpluses occur (which soil parameters have the greatest influence on the $\mathrm{N}$ surpluses?) and whether these $\mathrm{N}$ surpluses are closely related to the nitrate losses (measured values).

Site-specific $\mathrm{N}$ balances were calculated with input data collected using different methods to investigate the effect of different data sources and data quality on the $\mathrm{N}$ balance. Various soil properties, such as humus content, $\mathrm{N}$ content, electrical conductivity and available water capacity, were used to identify the causes of spatial variation of $\mathrm{N}$ surpluses.

Based on the current scientific knowledge, the hypotheses are that.

(1) $\mathrm{N}$ surpluses were highly variable within a uniformly fertilized field,

(2) even if $\mathrm{N}$ surplus is balanced, some parts of the field could have a large $\mathrm{N}$ surplus and therefore potential $\mathrm{N}$ losses,

(3) the $\mathrm{N}$ surpluses are related to soil parameters and yield zones,

(4) N surpluses determined with different digital methods show similar patterns of spatial variability on fields.

Based on the results, the relevance, effort required and benefits of site-specific $\mathrm{N}$ balancing were evaluated and recommendations for improving the precision of the technologies used were made.

\section{Materials and methods}

\section{Site and weather conditions}

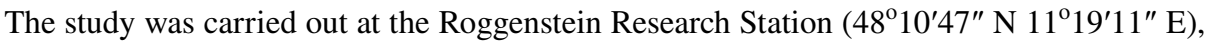
$30 \mathrm{~km}$ west of Munich (520 m a.s.1.). The soils examined at this experimental station are Cambisols (FAO 2014) of medium quality.

The 30-year mean annual precipitation was $954 \mathrm{~mm}$ and the mean annual temperature was $8.5^{\circ} \mathrm{C}$ (1981 to 2010) (Table 1$)$. The study year 2018 was characterized by a very dry and hot summer; 2018 was the hottest year on record at the location (DWD 2018).

The field "Bergfeld" was chosen as the study site because.

(a) it is of sufficient size (13.1 ha),

(b) soil properties and yield potential vary within the field (Spicker 2016),

(c) the field has been managed uniformly for many years.

Table 1 Mean temperature and precipitation, Research Station Roggenstein

\begin{tabular}{|c|c|c|c|c|c|c|}
\hline & Unit & $\begin{array}{l}\text { January to } \\
\text { March }\end{array}$ & April to June & $\begin{array}{l}\text { July to Sep- } \\
\text { tember }\end{array}$ & $\begin{array}{l}\text { October to } \\
\text { December }\end{array}$ & Year \\
\hline \multicolumn{7}{|l|}{2018} \\
\hline Temperature $\bar{x}$ & ${ }^{\circ} \mathrm{C}$ & 1.8 & 15.3 & 18.1 & 5.5 & 10.1 \\
\hline $\begin{array}{l}\text { Precipitation } \sum \\
1981-2010\end{array}$ & $\mathrm{~mm}$ & 160 & 277 & 276 & 155 & 867 \\
\hline Temperature $\bar{x}$ & ${ }^{\circ} \mathrm{C}$ & 1.0 & 12.5 & 16.4 & 4.2 & 8.5 \\
\hline Precipitation $\Sigma$ & $\mathrm{mm}$ & 175 & 276 & 302 & 201 & 954 \\
\hline
\end{tabular}




\section{Wheat production and $\mathbf{N}$ fertilizer application}

Winter wheat was analysed because wheat reacts explicitly to different soil qualities, is the most important crop with the largest acreage in the region and experimental data on wheat yield and $\mathrm{N}$ efficiency at the experimental station are available. The crop management is shown in Online Resource 1.

\section{Methods of determining plant variables}

The plant variables (Online Resource 2) required for the analyses were collected in 2018. In addition to digitally recorded plant variables, data from biomass samples and laboratory analyses are used as reference data.

On July 25, 2018, georeferenced biomass samples (50 areas, $2 \mathrm{~m}^{2}$ ) were cut by hand. Eight 2-m rows of wheat were cut using cordless clippers close to the ground. The grain was threshed in a laboratory thresher (Wintersteiger 2018). The grain dry matter (DM) content was determined after drying at $60{ }^{\circ} \mathrm{C}$ and the grain yield in tons ha ${ }^{-1}$, based on $86 \%$ DM, was calculated. Grain N content was determined using the Dumas combustion method.

To analyse the spatial variation of yield and $\mathrm{N}$ uptake of winter wheat, yield data from a combine harvester (volume flow sensor) (Noack 2007) from July 30, 2018 were used, together with satellite data from 2018 in combination with the plant growth model PROMET (Mauser and Bach 2009; ESA 2018), and data from reflectance measurements using a tractor-mounted multispectral sensor from June 7, 2018 (TEC5 2010; Maidl et al. 2019).

The mean wheat yield at the weighbridge was determined by weighing the tractor trailers.

\section{$N$ balancing}

The $\mathrm{N}$ surplus $\left(\mathrm{kg} \mathrm{ha}^{-1} \mathrm{a}^{-1}\right)$ was determined by $\mathrm{N}$ balancing:

$$
\mathrm{N} \text { surplus }=\mathrm{N}-\text { Input }-\mathrm{N} \text { - Output . }
$$

The $\mathrm{N}$ input is the amount of mineral $\mathrm{N}$ fertilizer application $\left(193 \mathrm{~kg} \mathrm{ha}^{-1}\right)$ for winter wheat that was applied uniformly on the test field (Online Resource 1). The $\mathrm{N}$ output is the grain $\mathrm{N}$ uptake. The $\mathrm{N}$ uptake was determined by (a) $\mathrm{N}$ content from laboratory analysis of biomass samples multiplied by grain yield from biomass samples, (b) grain yield (combine harvester volume flow sensor) multiplied by the mean $\mathrm{N}$ content (determined in grain samples from biomass sampling), (c) grain yield determined using the plant growth model PROMET (Mauser and Bach 2009) based on satellite data multiplied by the mean $\mathrm{N}$ content (determined in grain samples from biomass sampling) and (d) calculation of the vegetation index REIP based on reflectance measurements and an $\mathrm{N}$ uptake algorithm according to Maidl et al. (2019).

Byproducts (straw) were not harvested and therefore not considered as $\mathrm{N}$ output. The $\mathrm{N}$ surplus was calculated for each grid element (see Geostatistical analysis). 


\section{Methods of determining soil properties}

The soil properties (Online Resource 3) required for the analyses were collected from the "Bergfeld" in 2019 using georeferenced sampling. These were soil properties (e.g. soil texture, soil organic carbon content, soil total nitrogen content) that remain stable for several years in order to analyse relationships with plant variables determined in 2018.

Soil samples were taken on April 1, 2019 (soil layer 0-30 cm) for laboratory analysis of soil organic carbon (SOC) content, total nitrogen (TN) content, plant-available phosphorus $(\mathrm{P})$, plant-available potassium $(\mathrm{K})$ and $\mathrm{pH}$. Soil texture (soil layer 0-30 $\mathrm{cm}$ ) was determined by particle-size analysis and the available water capacity was calculated based on the soil texture (German soil mapping guideline, KA 5 2005).

A total of 100 soil samples based on $35 \mathrm{~m} \times 35 \mathrm{~m}$ grid cells were collected. The distribution of the soil samples within the field was "stratified random"- one single random location in each grid cell (Online Resource 4) (Thompson 2002). Eight soil samples were taken within a maximum radius of $50 \mathrm{~cm}$ around a georeferenced point, and mixed together to form a mixed sample.

The electrical conductivity (EM38 MK2) was measured on April 3, 2019.

To determine the amount of nitrate $\mathrm{N}$ below the root zone and the nitrate content in the leachate, soil cores were taken in three different yield zones ( 3 cores per zone) (Online Resource 4) (0 to $9 \mathrm{~m}$ depth) on October 14, 15 and 16 2019. The nitrate $\mathrm{N}$ stocks in the soil samples were determined in layers of $50 \mathrm{~cm}$.

\section{Descriptive statistics}

The mean, median, minimum, maximum and standard deviation were calculated for each variable using R (R Core Team 2020).

\section{Geostatistical analysis}

The data recorded by different methods varied greatly in spatial resolution and distribution:

- biomass samples (2018): 50 areas ( $2 \mathrm{~m}^{2}$ each),

- yield data, combine harvester volume flow sensor (2018): 6623 points,

- yield data from the PROMET plant growth model, based on satellite data (2018): 1336 grid elements $(10 \mathrm{~m} \times 10 \mathrm{~m})$,

- sensor data, TEC 5, tractor mounted (2018): 5324 points,

- soil properties, soil samples (2019): 100 points,

- apparent electrical conductivity data, (EM38 MK2) (2019): 8889 points.

The data were transferred to grids of the same resolution $(10 \mathrm{~m} \times 10 \mathrm{~m})$ and with the same raster elements (1 163 grids); raster input data by downsampling and point input data by interpolation to the raster elements using block kriging $(10 \mathrm{~m} \times 10 \mathrm{~m}$ blocks) (Oliver and Webster 2015). A variogram (variance of the data according to distance classes) of the data was created, which shows the spatial relationship of the variable with increasing separating distance (spatial auto-correlation effect). A model was fitted to the variogram, which is used for weighting data in the kriging neighbourhood to predict values at unsampled places (Hengl 2007; Oliver and Webster 2015). The results of variogram analysis are shown in Online Resources 6 and 7. 


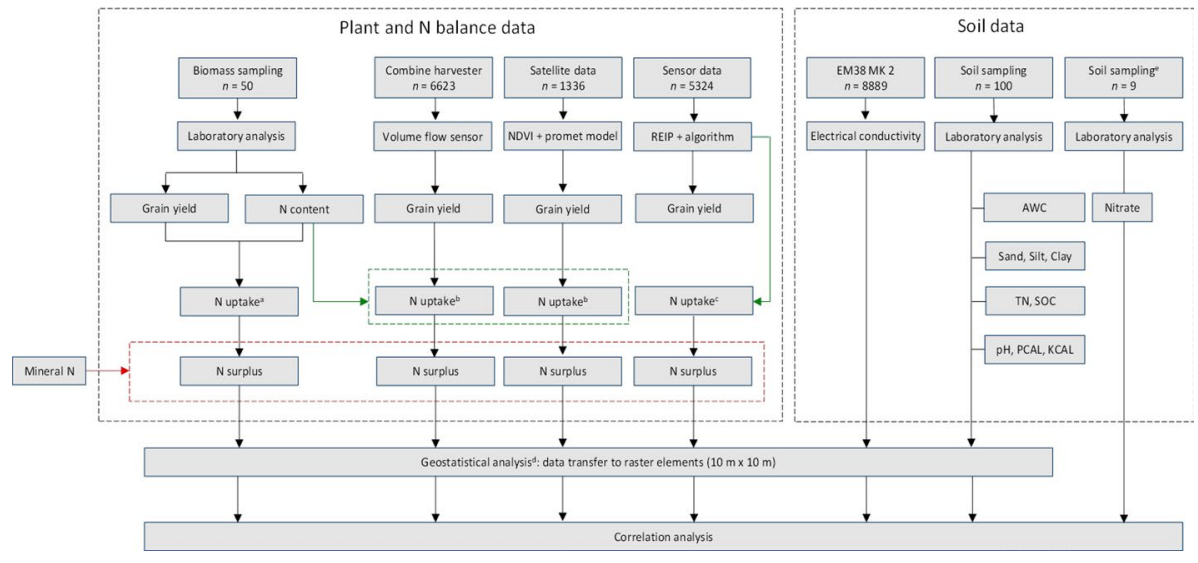

Fig. 1 Flow chart of the consecutive work steps in this study

The outer $10 \mathrm{~m}$ of the field were not included in data analysis (Online Resource 4) to avoid evaluating data from areas that do not belong to the field. A correlation analysis based on the grid elements was carried out to check the relationships between the plant and soil variables. The R libraries "rgdal", "rgeos", "gstat" and "raster" were used for spatial analyses and for loading vector or raster files. The correlation coefficients $(r)$ were classified as very strong $(r>0.9)$, strong $(0.9>r>0.7)$, moderate $(0.7>r>0.5)$, weak $(0.5>r>0.3)$ or very weak $(r<0.3)$.

Figure 1 is a flowchart that shows the consecutive work steps for determining plant, $\mathrm{N}$ balance and soil variables as well as the subsequent geostatistical and correlation analysis.

(a) Use of measured $\mathrm{N}$ content from biomass samples $(n=50)$ for calculation of $\mathrm{N}$ uptake; (b) use of mean $\mathrm{N}$ content from biomass samples for calculation of $\mathrm{N}$ uptake; (c) calculation of the $\mathrm{N}$ uptake using the REIP vegetation index and algorithms; (d) Kriging; (e) deep drilling.

\section{Results}

\section{Spatial variation of wheat yield}

The results in Fig. 2 and Table 2 show that different methods analysis and different spatial resolutions led to different results in terms of mean wheat grain yields, as well as different yield distribution patterns and different yield variation.

The wheat grain yield from the biomass samples varied between 6.3 and 12.9 tons ha ${ }^{-1}$. The wheat grain yields measured by the volume flow sensor of the combine harvester were also highly variable (6.2-16.0 tons $\left.\mathrm{ha}^{-1}\right)$, as was the grain yield measured by satellite (5.2-10.3 tons $\left.\mathrm{ha}^{-1}\right)$ and sensor (6.1-10.0 tons ha ${ }^{-1}$ ) (Table 2).

The mean grain yield determined from biomass samples was larger (9.9 tons $\mathrm{ha}^{-1}$ ) than the mean yield determined by the combine harvester $\left(9.4\right.$ tons ha $\left.{ }^{-1}\right)$. The mean yield 
Fig. 2 Yield maps. Yield derived from the combine harvester (volume flow sensor), satellite (PROMET model) and tractormounted sensor (REIP + algorithms)

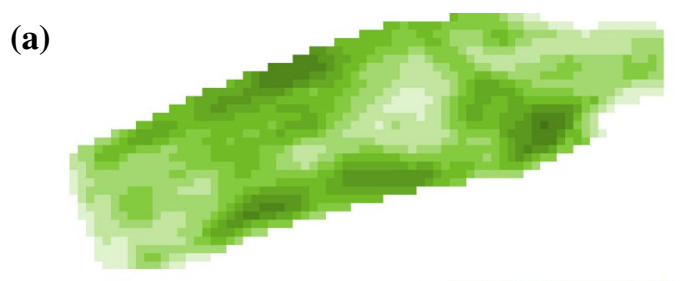

(b)

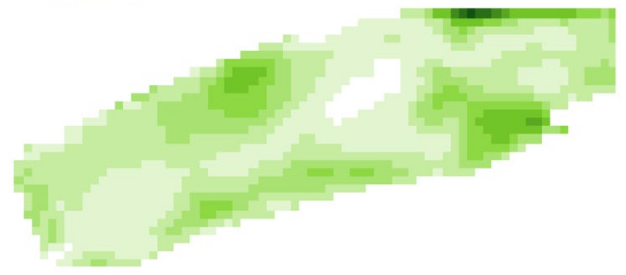

(c)

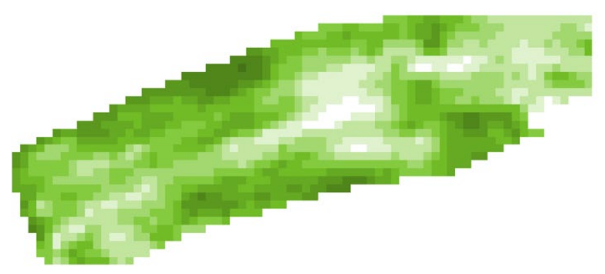
a) Harvester
b) Satellite
c) Sensor

modelled using satellite data and the PROMET model was considerably lower at 6.7 tons $\mathrm{ha}^{-1}$ and the mean yield using sensor data and algorithms was 8.0 tons $\mathrm{ha}^{-1}$. The mean wheat yield at the weighbridge was 7.9 tons $\mathrm{ha}^{-1}$, which was $16 \%$ less than the mean yield determined using the combine harvester, $17 \%$ more than the mean yield determined using satellite data and it fitted well with the sensor data. However, the entire field was included in the yield at the weighbridge, while $10 \mathrm{~m}$ at the edge of the field were not included in the data analysis when all digital data were analysed (see Materials and methods section, and Online Resource 4).

\section{Spatial variation of $\mathbf{N}$ uptake}

Calculated grain $\mathrm{N}$ uptake was highly variable: biomass samples (142-257) $\mathrm{kg} \mathrm{ha}^{-1}$, combine harvester yield data (121-310) $\mathrm{kg} \mathrm{ha}^{-1}$, satellite data and modelling (102-199 kg $\mathrm{ha}^{-1}$ ) and sensor measurements (102-269 $\mathrm{kg} \mathrm{ha}^{-1}$ ) (Table 2; Fig. 3).

The mean $\mathrm{N}$ uptake determined from the biomass samples was $190 \mathrm{~kg} \mathrm{ha}^{-1}$ larger than the mean yield determined using the combine harvester $\left(182 \mathrm{~kg} \mathrm{ha}^{-1}\right)$, satellite data 


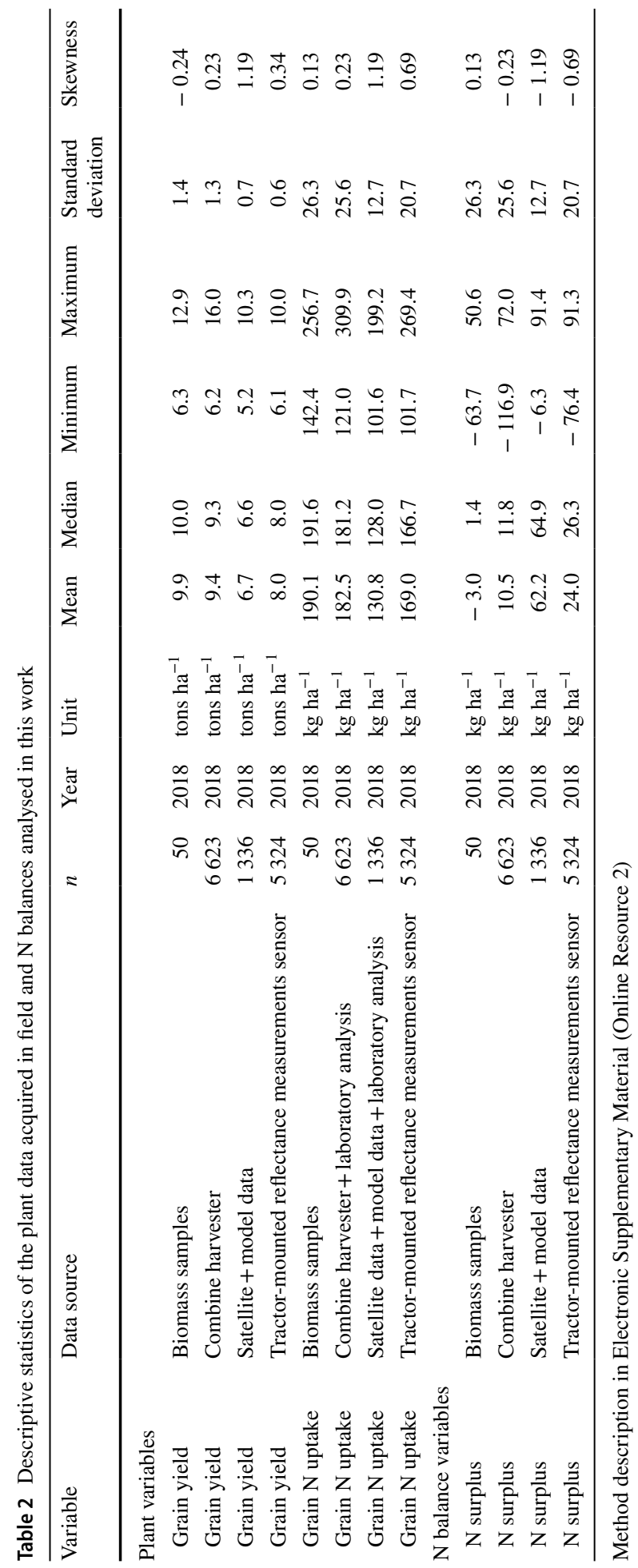


(a)

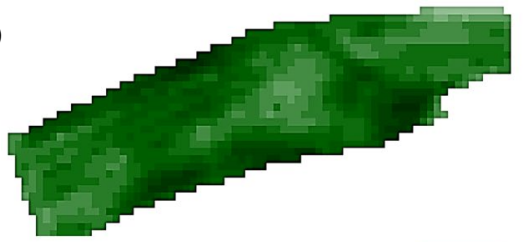

(b)

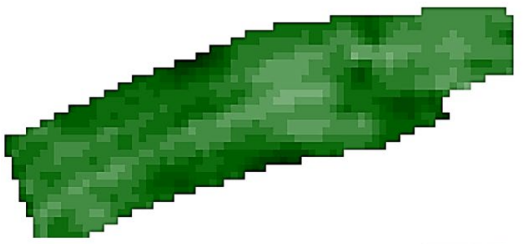

(c)
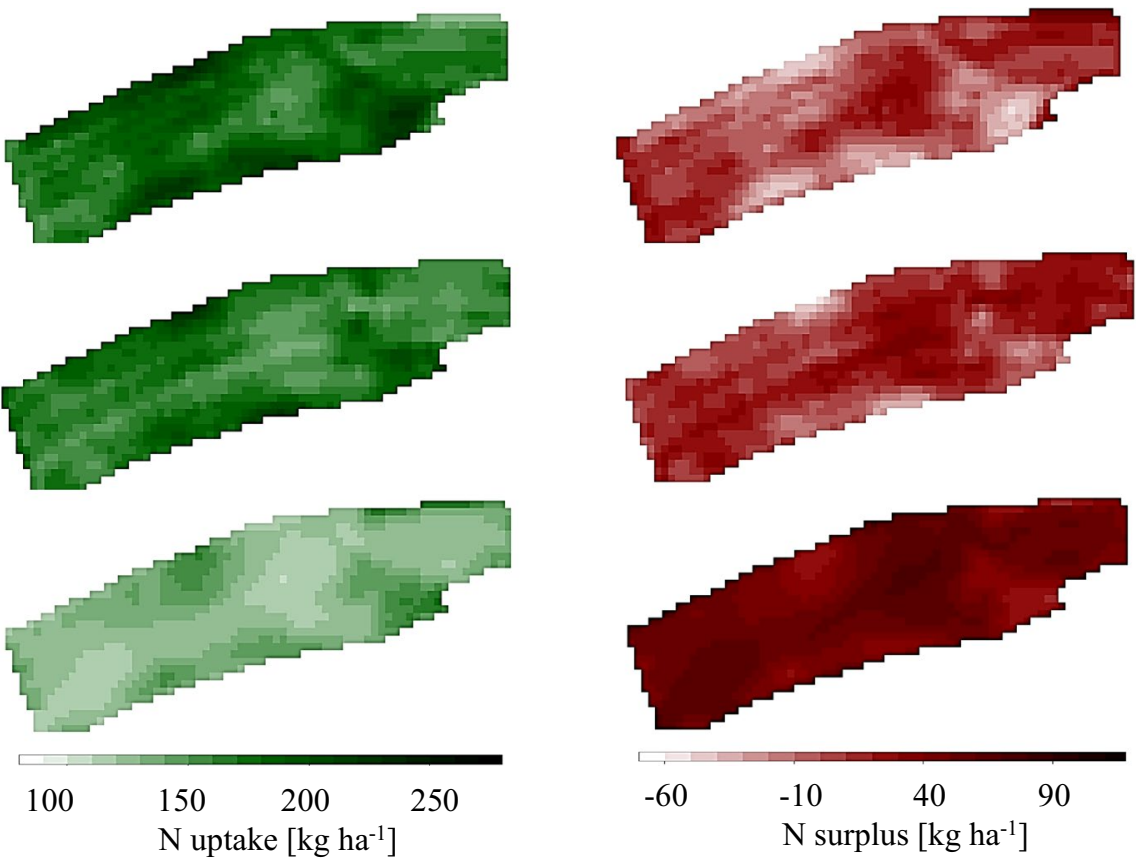

a) Based on combine harvester (volume flow sensor)

b) Based on tractor mounted sensor (reflectance measurement)

c) Based on satellite (reflectance measurement)

Fig. $3 \mathrm{~N}$ uptake (grain) and $\mathrm{N}$ surplus (kriged maps) calculated by different methods

$\left(131 \mathrm{~kg} \mathrm{ha}^{-1}\right)$ or sensor measurements $\left(169 \mathrm{~kg} \mathrm{ha}^{-1}\right)$. Mean grain $\mathrm{N}$ uptake based on the average yield (at the weighbridge) was $157 \mathrm{~kg} \mathrm{ha}^{-1}$.

\section{Spatial variation of $\mathbf{N}$ surplus}

Calculated grain $\mathrm{N}$ surplus were also highly variable: biomass samples ( -64 to 51$) \mathrm{kg}$ $\mathrm{ha}^{-1}$, combine yield data ( -117 to 72$) \mathrm{kg} \mathrm{ha}^{-1}$, satellite data and modelling ( -6 to 91) $\mathrm{kg}$ $\mathrm{ha}^{-1}$ and sensor measurements ( -76 to $91 \mathrm{~kg} \mathrm{ha}^{-1}$ ) (Fig. 3).

The mean $\mathrm{N}$ surplus determined from the biomass samples at 50 measurement points was $-3 \mathrm{~kg} \mathrm{ha}^{-1}$. The mean $\mathrm{N}$ surplus determined using the combine harvester was $10 \mathrm{~kg}$ $\mathrm{ha}^{-1}$, using satellite data $62 \mathrm{~kg} \mathrm{ha}^{-1}$, and sensor measurements $24 \mathrm{~kg} \mathrm{ha}^{-1}$. Mean grain $\mathrm{N}$ surplus based on the average yield (at the weighbridge) was $36 \mathrm{~kg} \mathrm{ha}^{-1}$.

Thus, the mean $\mathrm{N}$ surplus calculated using sensor measurements was similar to the mean $\mathrm{N}$ surplus of the field based on weighbridge data. Satellite data resulted in larger $\mathrm{N}$ surpluses being calculated due to the relatively small yields and $\mathrm{N}$ uptake. 


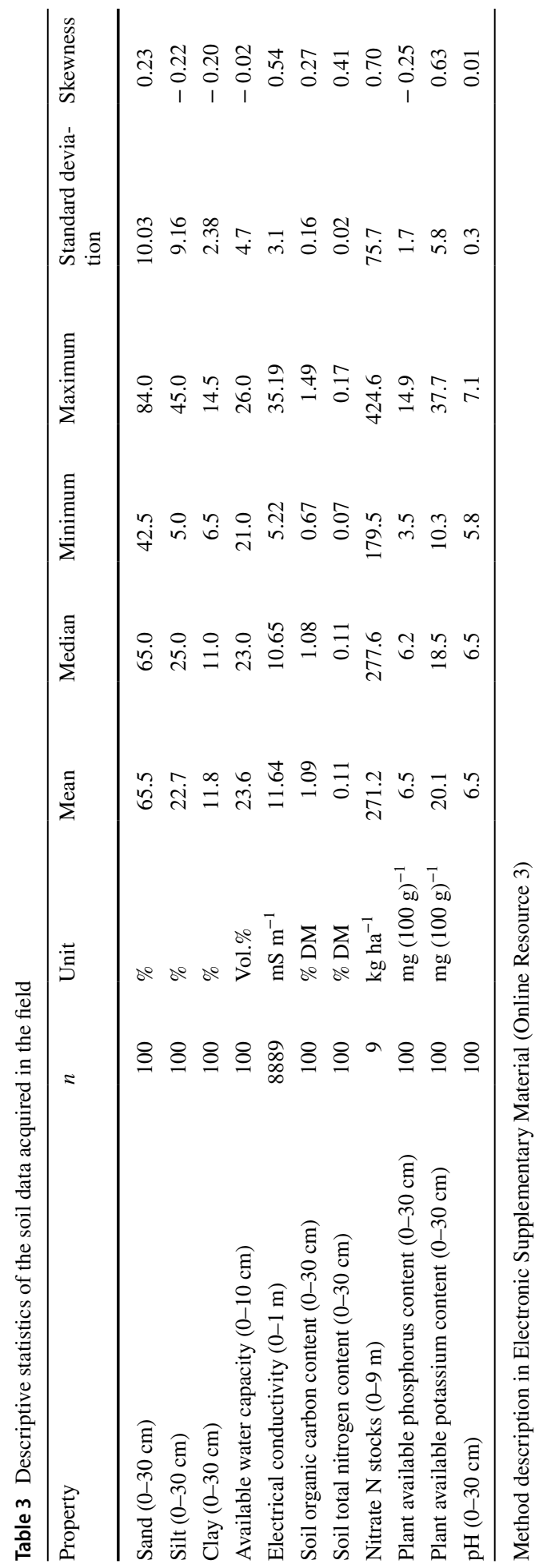




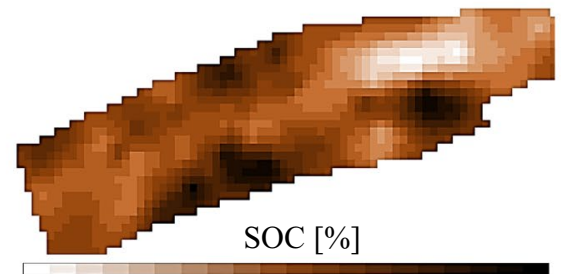

0.8

1.0

1.2

1.4

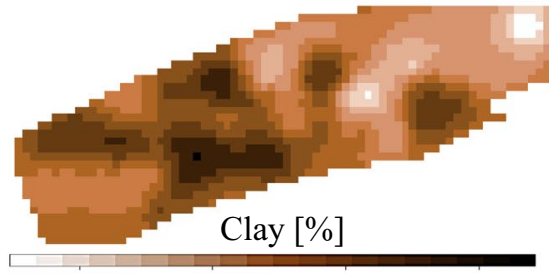

10

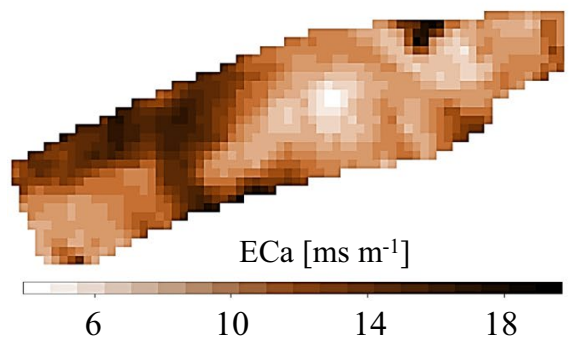

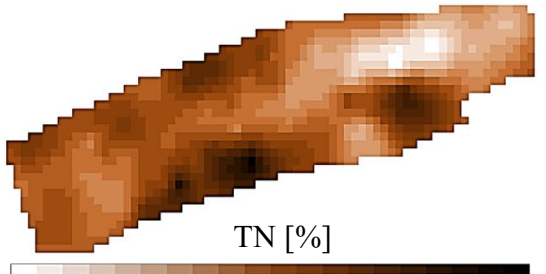

$0.08 \quad 0.10 \quad 0.12 \quad 0.14$
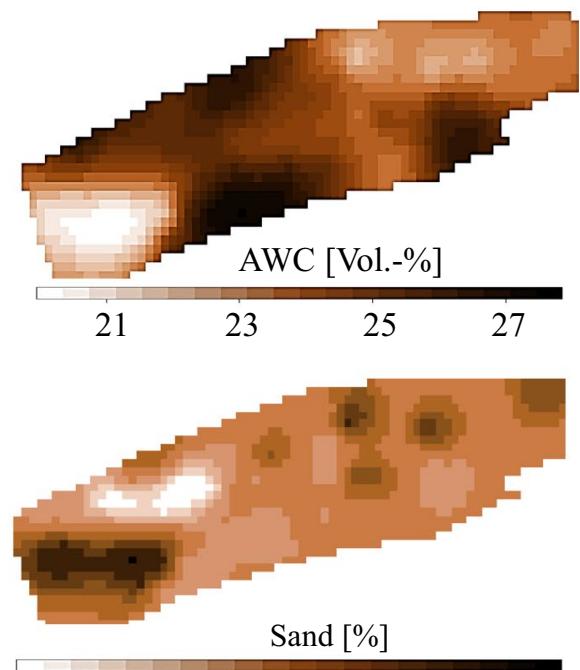

50

60

70

80

Fig. 4 Spatial distribution (kriged maps) for six soil properties in the study area. SOC soil organic carbon content, $T N$ soil total nitrogen content, Clay, $A W C$ available water capacity, ECa apparent electrical conductivity, Sand

\section{Spatial variation of soil properties}

The soil properties all varied greatly within the field (Table 3; Fig. 4). Some of the soil properties showed similar patterns of distribution, e.g. the SOC content, the TN content and the available water capacity (Fig. 4). Mean values were: sand $65.5 \%$, silt $22.7 \%$, clay $11.8 \%$, available water capacity 23.6 vol. $\%$, electrical conductivity $11.64 \mathrm{mS} \mathrm{m}^{-1}$, SOC content $1.09 \%$, TN content $0.11 \%$, P content $6.5 \mathrm{mg}(100 \mathrm{~g})^{-1}, \mathrm{~K}$ content $20.1 \mathrm{mg}(100 \mathrm{~g})^{-1}$ and $\mathrm{pH} 6.5$ (the additional soil properties are shown in Online Resource 5).

The soil cores (deep drilling, soil layer 0 to $9 \mathrm{~m}$ ) showed that nitrate $\mathrm{N}$ stocks differed between the yield zones (Online Resource 4). Nitrate $\mathrm{N}$ amounts of 277 to $424 \mathrm{~kg} \mathrm{ha}^{-1}$ 
were found in the low-yield zone, 215 to $337 \mathrm{~kg} \mathrm{ha}^{-1}$ in the medium-yield zone and in the high-yield zone they were 179 to $202 \mathrm{~kg} \mathrm{ha}^{-1}$ (average of three cores). The mean nitrate $\mathrm{N}$ amounts in the low-yield zone were higher $\left(342 \mathrm{~kg} \mathrm{ha}^{-1}\right)$ than in the medium-yield zone $\left(278 \mathrm{~kg} \mathrm{ha}^{-1}\right)$ and the high-yield zone $\left(192 \mathrm{~kg} \mathrm{ha}^{-1}\right)$ (average of three cores).

\section{Correlation between variables}

\section{Grain yield, $\mathbf{N}$ uptake, and $\mathbf{N}$ surplus}

The correlations between the yield determined from biomass samples and from the digital methods were moderate: combine harvester $(r=0.66)$, satellite $(r=0.56)$ and sensor $(r=0.63)$. The correlations (grain yield) between combine harvester and sensor and between sensor and satellite were strong $(r=0.77$ and 0.71 , respectively) and moderate between combine harvester and satellite $(r=0.57)$ (Table 4$)$.

The yield and $\mathrm{N}$ uptake (combine harvester) were weakly to moderately correlated with the following soil properties: available water capacity $(r=0.63)$, TN content $(r=0.61)$, SOC content $(r=0.60)$, electrical conductivity $(r=0.48)$, clay content $(r=0.42)$, and sand content $(r=-0.37)$.

The $\mathrm{N}$ uptake (sensor data) was similarly correlated with the soil properties (moderate to very weak): TN content $(r=0.58)$, SOC content $(r=0.56)$, electrical conductivity $(r=0.56)$, available water capacity $(r=0.54)$, clay content $(r=0.37)$, sand content $(r=$ $-0.29)$.

The $\mathrm{N}$ uptake based on satellite data showed similar (but weaker) relationships to the soil properties. Soil phosphorus and potassium contents had a weak influence only (weak to very weak) on the yield, $\mathrm{N}$ uptake and $\mathrm{N}$ balance.

Therefore, high wheat $\mathrm{N}$ uptake occurred when TN and SOC content were also large, as well as when available water capacity was high.

The calculated $\mathrm{N}$ balances were derived directly from the yield data or $\mathrm{N}$ uptake. They therefore correlated negatively with the properties TN, SOC and available water capacity. The correlations of surplus $\mathrm{N}$ to all other properties (except sand) were all negative (with respect to the $\mathrm{N}$ uptake). Nitrogen surplus was higher when TN, SOC and available water capacity were lower.

There was a strong correlation of $r=0.82$ between the georeferenced $\mathrm{N}$ surplus (determined using the sensor) and the nitrate $\mathrm{N}$ stocks ( 0 to $9 \mathrm{~m}$ ).

\section{Soil properties}

The SOC content and TN content correlated very strongly $(r=0.97)$ (Table 4). The available water capacity correlated moderately with the SOC $(r=0.69)$ and TN content $(r=0.69)$, and with the electrical conductivity $(r=0.52)$. The electrical conductivity had a weak relationship to TN content $(r=0.48)$ and SOC content $(r=0.40)$. 


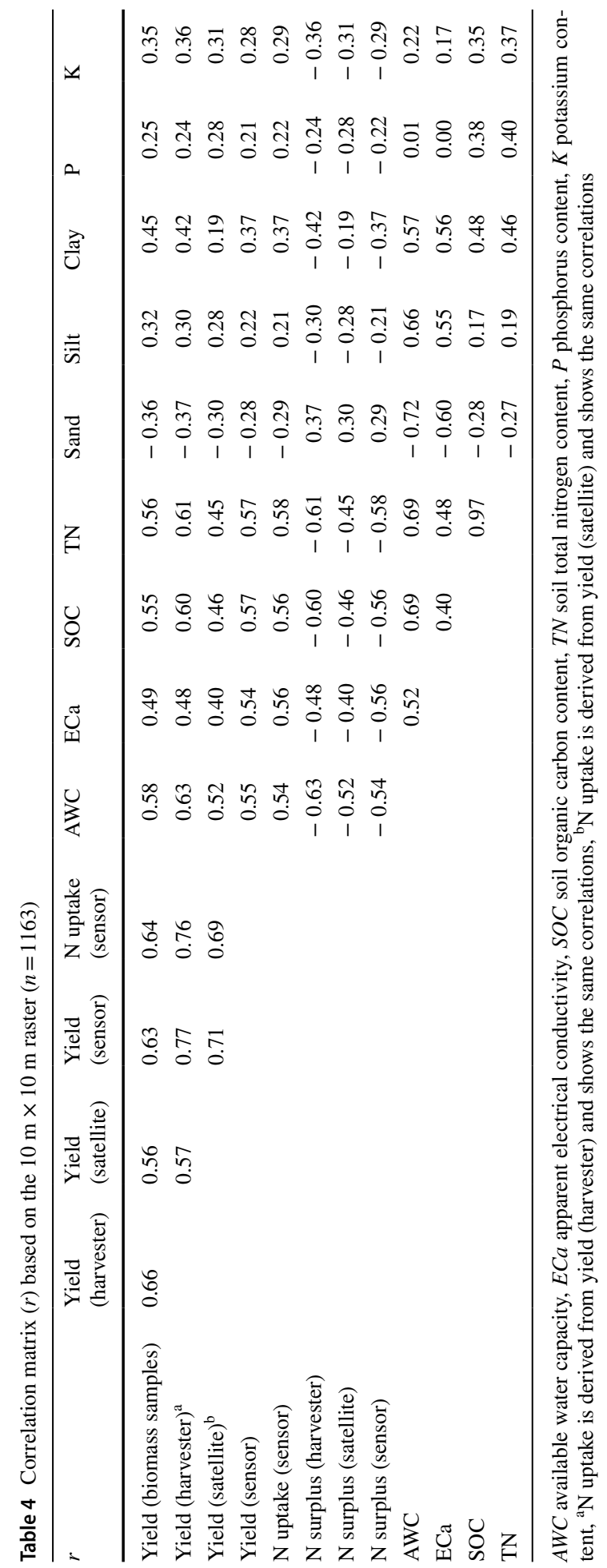




\section{Discussion}

\section{Discussion of methods}

In this study, georeferenced plant, $\mathrm{N}$ balance and soil variables were determined on a 13-ha heterogeneous field using different data sources and methods, and relationships between these variables were analysed.

\section{Site selection}

The results were influenced by the properties (size, heterogeneity) of the field. A relatively large (13 ha) arable field was selected for the study. Even though the whole field has been cultivated uniformly for decades, there is spatial variation in soil properties and yield potential (Spicker 2016).

The small-scale variation in soil and yield in this field is characteristic of the site conditions in the study region (Auerswald et al. 1997; Heil and Schmidhalter 2017) whereas in other agricultural regions (e.g. on homogeneous loess Chernozem soils) there may be considerably less variation (Roßkopf et al. 2015). Site-specific management, taking spatially variable soil properties and yield potentials into account, is sensible and necessary on heterogeneous fields only (Whelan 2018).

\section{Origin of data and technologies used}

Plant and soil variables were measured using various digital methods. The different numbers of measurement points must also be taken into account. For applications in precision farming, very different data from different sources and analytical methods are generally available, some of which can be used free of charge (satellite data), some of which require more complex (e.g. combine harvester volume flow sensor) and/or more expensive analyses (e.g. tractor-mounted sensor systems) (Finger et al. 2019). In this study, "ground truth" data were also obtained (e.g. yield determination using biomass sampling, SOC and TN content measurements and soil cores (down to $9 \mathrm{~m}$ ) to determine soil nitrate content below the root zone) so that modelled data could be compared to measured data. It was therefore possible to evaluate the different digital methods.

\section{$N$ balancing}

In this study, site-specific $\mathrm{N}$ balances were calculated based on measured data and modelled data (yield, grain $\mathrm{N}$ uptake); mineral $\mathrm{N}$ fertilizer application was carried out uniformly across the field. The difference between grain $\mathrm{N}$ uptake ( $\mathrm{N}$ output) and $\mathrm{N}$ fertilizer applied ( $\mathrm{N}$ input) is the simplest method of calculating the $\mathrm{N}$ surplus. Other influencing factors, such as $\mathrm{N}$ mineralization and $\mathrm{N}$ immobilization (Hülsbergen 2003), as well as $\mathrm{N}$ deposition, are not taken into account using this method. In principle, however, it will be possible to record these processes in a spatially differentiated manner in the future, e.g. through the use of soil process models and satellite data (Mauser and Bach 2009). Soil N dynamics, in particular $\mathrm{N}$ mineralization from the soil $\mathrm{N}$ pool, can vary greatly depending on soil conditions and have a considerable effect on biomass production, $\mathrm{N}$ uptake and 
ultimately also the $\mathrm{N}$ surpluses and $\mathrm{N}$ use efficiency (Prücklmaier 2020). Nitrogen mineralization was not measured in this study, but the total nitrogen content (TN) was measured.

\section{Geostatistics}

The distribution of the soil samples according to the "stratified random" (one single location in each grid cell) method meant the distance between the sampling points and the distribution of the area under investigation were taken into account more effectively than if a strict grid had been used (Thompson 2002). 100 Soil sampling points and 50 biomass sampling areas $\left(2 \mathrm{~m}^{2}\right)$ for a 13-ha arable field were sufficient for the geostatistical evaluation. A major advantage of kriging is that the prediction variance can also be calculated from the location of the sampling points. As a result, the prediction error is influenced by the number and location of the measurement points; it is independent of the value of the measurements (Delhomme 1978; Oliver and Webster 2015).

Through the interpolation and formation of a $10 \mathrm{~m} \times 10 \mathrm{~m}$ grid, single extreme values were smoothed by the values of the neighbouring grid cells. As a result, the values in the calculated grids had a smaller range (min-max) than the original data.

\section{Discussion of results}

\section{Spatial variation in wheat yields in relation to soil properties}

The spatial variation in wheat yields was considerable (grain yield: 6 to 13 tons ha ${ }^{-1}$ ). Although there were many factors influencing yield, the available water capacity $(r=0.63)$, TN content $(r=0.61)$ and SOC content $(r=0.60)$ had the largest influence (harvester). These soil properties are relatively stable (changeable only in the long term) (Körschens 2010; Wiesmeier et al. 2019), it can be expected that the yield and $\mathrm{N}$ uptake patterns dependent on them are also relatively stable. The SOC content can be used as a proxy for the humus content of the soil; humus has a positive influence on numerous soil processes, soil properties (e.g. soil structure, soil biology, nutrient content) and crop yield, as has been found in numerous studies (Tiessen et al. 1994; FAO 2001; Pan et al. 2009; Leithold et al. 2015). The SOC content correlated very strongly with the TN content $(r=0.97)$ and moderately with the available water capacity $(r=0.69)$. Soil water storage has a significant effect on yield formation particularly in dry years such as 2018 . The available water often limits the yield (Godwin and Miller 2003).

The results showed that the volume flow sensor on the combine harvester overestimated the yield $\left(9.4\right.$ tons $\left.\mathrm{ha}^{-1}\right)$ compared to the average yield of the field $\left(7.9\right.$ tons ha $\left.{ }^{-1}\right)$ measured using the weighbridge. This could be due to (a) inaccuracies in the volume flow measurements of the sensor (Bachmaier 2007) and (b) the removal of data at the edge of the field $(10 \mathrm{~m}$ ) (see section geostatistical analysis). Yields at the field edge were recorded at the weighbridge, but were excluded from the combine harvester, satellite and tractor sensor data analysis. The method based on satellite data combined with the PROMET model, however, underestimated the yield $\left(6.7\right.$ tons $\left.\mathrm{ha}^{-1}\right)$.

The analysis of the correlations between the yield and $\mathrm{N}$ balance variables using different methods showed that there was a strong relationship between combine harvester and tractor mounted sensor $(r=0.77)$ and between sensor and satellite $(r=0.71)$ measurements. The correlation between satellite data and combine harvester data was weaker $(r=0.57)$. 
Combine harvester and sensor data correlated more strongly with the soil properties than the satellite data. Kaivosoja et al. (2019) compared tractor-mounted sensor data, combine yield data and Sentinel 2 satellite data. They found stronger, but similar results (e.g. combine harvester and tractor mounted sensor, $r=0.82$; satellite and tractor mounted sensor, $r=0.80$; combine harvester and satellite, $r=0.75$ ). Křížová and Kumhálová (2017) compared selected remote sensing sensors to estimate the variation in crop yield at two different locations; they found weaker correlations (e.g. GreenSeeker crop sensor data and Landsat satellite data, $r=0.35,0.67$ respectively).

It should be noted, therefore, that the spatial distribution of yield, $\mathrm{N}$ uptake and $\mathrm{N}$ surplus is still subject to considerable error when determined by methods used in this study, so that the yield zones (e.g. high and low yield zones or the zones with different $\mathrm{N}$ surpluses and nitrate loss potentials) cannot yet be determined precisely.

To improve precision of the analysis further, the digital technologies must be further improved or their application optimized, e.g. by:

- higher spatial resolution of the satellite data (Mulla 2013; Segarra et al. 2020),

- data fusion (Castrignanò et al. 2018; Shaddad 2019),

- further development of the algorithms (sensor) and the models (satellite).

The accuracy and informative value of the measured values (biomass samples, soil samples) could also be increased by increasing the number of samples, although this can only be implemented in scientific studies, but not in practice.

\section{Spatial variation of the $\mathbf{N}$ surpluses}

The analyses showed that the $\mathrm{N}$ surpluses were highly variable within a uniformly fertilized field. The largest mean grain $\mathrm{N}$ uptake and smallest $\mathrm{N}$ surpluses were calculated using the combine harvester yield data, the lowest grain $\mathrm{N}$ uptake and highest $\mathrm{N}$ surpluses were calculated using satellite data and the PROMET model.

The $\mathrm{N}$ surplus indicates the total potential $\mathrm{N}$ loss (Klein et al. 2017). However, the absolute amount of different nitrogen losses (nitrate, ammonia or nitrous oxide) remains unknown. Investigations by Hülsbergen et al. (2017) showed significant relationships between $\mathrm{N}$ surpluses and measured nitrate losses in 23 fields (measured using soil cores to a depth of $9 \mathrm{~m}$ and nitrate analyses). The $\mathrm{N}$ surpluses were calculated as means of the fields, while the soil cores were taken in high and low yield zones. In the present study, however, both the $\mathrm{N}$ surpluses were calculated and the soil cores were taken site-specifically and georeferenced and there was a strong relationship $(r=0.82)$ between the $\mathrm{N}$ surplus and nitrate $\mathrm{N}$ stocks. Further studies (in a large number of arable fields at different locations and with differing management) are needed to clarify whether site-specific $\mathrm{N}$ balancing generally leads to a better estimate of nitrate losses.

\section{Conclusions and outlook}

Site-specific management can reduce the ecological footprint of agriculture (Walter et al. 2017). There are different methods of site-specific cultivation of farmland, site-specific $\mathrm{N}$ fertilizer application is a promising approach. The study of the spatial variation of $\mathrm{N}$ 
surpluses on a uniformly fertilized field underline the necessity of site-specific $\mathrm{N}$ fertilizer application.

Based on the results, the combine harvester yield data are suitable for estimating the spatial variation in yields, $\mathrm{N}$ uptake and $\mathrm{N}$ balances. The main advantage of this method is that data collection is simple and inexpensive using modern combine harvesters. The accuracy of the determination of the $\mathrm{N}$ uptake could possibly be improved if, in the future, the protein and $\mathrm{N}$ content are also determined by NIRS sensors directly on the combine harvester (Dinamica generale 2020).

In these analyses, the satellite data showed the weakest correlations and the greatest deviation from the measured values (although the differences to the other methods were not particularly great). One problem is the relatively high resolution $(10 \mathrm{~m} \times 10 \mathrm{~m})$ of the satellite data. On the other hand, a higher spatial resolution would not have any advantage for farmers because, for example, the fertilizer spreaders used today (with partial working widths of $12 \mathrm{~m}$ ) do not work on a smaller scale.

The tractor-mounted sensors gave the best results in this investigation (strongest correlations, best agreement with the ground truth values). They still have development potential, for example through better algorithms (Ali and Deo 2020). In addition, their use is currently still associated with excessive costs, which can, however, be minimized through inter-farm cooperation.

The examination of the hypotheses results in the following evaluation:

Hypothesis 1 N surpluses were highly variable within a uniformly fertilized field. All digital methods used showed a high variation of the $\mathrm{N}$ surpluses; sub areas with negative $\mathrm{N}$ surpluses and sub areas with high $\mathrm{N}$ surpluses were identified (Table 2). Nitrogen surpluses (sensor data) of the raster elements $(n=1163)$ were calculated from -76.4 to $91.3 \mathrm{~kg} \mathrm{ha}^{-1}$, with a mean of $24.0 \mathrm{~kg} \mathrm{ha}^{-1}$.

Hypothesis 2 even if $N$ surplus is balanced, some parts of the field could have a large $N$ surplus and therefore potential $N$ losses. Although the $\mathrm{N}$ surplus was almost balanced in the mean of the whole field, $\mathrm{N}$ surpluses up to $90 \mathrm{~kg} \mathrm{ha}^{-1} \mathrm{a}^{-1}$ were determined on sub areas. There was a strong correlation between the measured nitrate content and calculated $\mathrm{N}$ surplus $(\mathrm{r}=0.82)$.

Hypothesis 3 The $N$ surpluses are related to soil parameters and yield zones. The correlation analyses (Table 4) show that the variability of the $\mathrm{N}$ surpluses is related to soil and plant parameters. Soil organic carbon correlated very strongly with total nitrogen content $(\mathrm{r}=0.97)$, moderately with $\mathrm{N}$ uptake (sensor, $\mathrm{r}=0.60)$ and negatively with $\mathrm{N}$ surplus (satellite, $r=-0.46$; sensor, $r=-0.56$; harvester, $r=-0.60)$.

Hypothesis $4 \mathrm{~N}$ surpluses determined with different digital methods show similar patterns of spatial variation on fields. The correlations between the digital methods were $r=0.57$ to 0.77 , but the $\mathrm{N}$ surpluses determined from satellite data deviated significantly from the values of the other digital methods and the measurement data (Table 2; Fig. 3).

Thus, Hypotheses 1 to 3 are confirmed, Hypothesis 4 is rejected.

There are only a few scientific studies about site-specific $\mathrm{N}$ balances using different data sources. The method enables the potential $\mathrm{N}$ loss within fields to be determined with a high spatial resolution. In particular in regions with a large risk of nitrate leaching and in areas 
protected for drinking water that have large and/or increasing nitrate content in groundwater, site-specific $\mathrm{N}$ balancing can contribute to a reduction of nitrogen losses.

\section{Further research}

Further research is needed,

(a) whether $\mathrm{N}$ surpluses within fields are also highly variable in other crops, and for other soil and climatic conditions,

(b) whether there is less variation in $\mathrm{N}$ surpluses (and overall smaller $\mathrm{N}$ losses) in the case of sensor-based site-specific $\mathrm{N}$ fertilizer application compared to uniform $\mathrm{N}$ application,

(c) how the precision and accuracy of the digital technologies for the site-specific determination of plant, soil and $\mathrm{N}$ balance variables can be improved further,

(d) whether the determination of soil properties can also be carried out using digital methods, e.g. drones or proximal laser sensor systems.

Supplementary Information The online version of this article (https://doi.org/10.1007/s11119-021-09789 -9) contains supplementary material, which is available to authorized users.

Acknowledgements Great thanks to VISTA Geowissenschaftliche Fernerkundung GmbH (Gabelsbergerstraße 51, 80333 Munich, Germany) for providing a yield map using satellite data and a crop growth model.

Funding Open Access funding enabled and organized by Projekt DEAL. This study was funded by the German Federal Environmental Foundation (Deutsche Bundesstiftung Umwelt).

\section{Compliance with ethical standards}

Conflict of interest The authors declare that they have no conflict of interest.

Open Access This article is licensed under a Creative Commons Attribution 4.0 International License, which permits use, sharing, adaptation, distribution and reproduction in any medium or format, as long as you give appropriate credit to the original author(s) and the source, provide a link to the Creative Commons licence, and indicate if changes were made. The images or other third party material in this article are included in the article's Creative Commons licence, unless indicated otherwise in a credit line to the material. If material is not included in the article's Creative Commons licence and your intended use is not permitted by statutory regulation or exceeds the permitted use, you will need to obtain permission directly from the copyright holder. To view a copy of this licence, visit http://creativecommons.org/licenses/by/4.0/.

\section{References}

Ali, M., \& Deo, R. C. (2020). Modeling wheat yield with data-intelligent algorithms. In P. Samui (Ed.), Handbook of probabilistic models (pp. 37-87). Oxford: Elsevier.

Auerswald, K., Sippel, R., Kainz, M., Demmel, M., Scheinost, A., \& Maidl, F. (1997). The crop response to soil variability in an agroecosystem. CATENA, 30, 39-53.

Bachmaier, M. (2007). Using a robust variogram to find an adequate butterfly neighborhood size for onestep yield mapping using robust fitting paraboloid cones. Precision Agriculture, 8(1-2), 75-93.

Castrignanò, A., Buttafuoco, G., Quarto, R., Parisi, D., Viscarra Rossel, R. A., Terribile, F., et al. (2018). A geostatistical sensor data fusion approach for delineating homogeneous management zones in Precision Agriculture. CATENA, 167, 293-304. 
Dalgaard, T., Bienkowski, J. F., Bleeker, A., Dragosits, U., Drouet, J. L., Durand, P., et al. (2012). Farm nitrogen balances in six European landscapes as an indicator for nitrogen losses and basis for improved management. Biogeosciences, 9(12), 5303-5321.

de Klein, C. A. M., Monaghan, R. M., Alfaro, M., Gourley, C. J. P., Oenema, O., \& Powell, J. M. (2017). Nitrogen performance indicators for dairy production systems. Soil Research, 55(6), 479-488.

Delhomme, J. P. (1978). Kriging in the hydrosciences. Advances in Water Resources, 1(5), 251-266.

Dinamica generale. (2020). Evo NIR: Electronic solutions and sensors. Retrieved October 21, 2020, from https://www.dinamicagenerale.com/de-ww/evonir.aspx.

DWD. (2018). Weather in Germany 2018. Retrieved November 24, 2020, from https://www.dwd.de/DE/ presse/pressemitteilungen/DE/2018/20181228_deutschlandwetter_jahr2018_news.html.

ESA. (2018). European Space Agency: Sentinel-2. Retrieved October 21, 2020, from https://sentinel. esa.int/web/sentinel/missions/sentinel-2.

FAO. (2001). Soil carbon sequestration for improved land management. World soil resource reports. Rome: Food and Agriculture Organziation of the United Nations.

FAO. (2014). World reference base for soil resources 2014: International soil classification system for naming soils and creating legends for soil maps. World soil resources reports. Rome: Food and Agriculture Organization of the United Nations.

Finger, R., Swinton, S., El Benni, N., \& Walter, A. (2019). Precision farming at the nexus of agricultural production and the environment. Annual Review of Resource Economics, 11(1), 313-335.

Frogbrook, Z. L., \& Oliver, M. A. (2007). Identifying management zones in agricultural fields using spatially constrained classification of soil and ancillary data. Soil Use and Management, 23(1), 40-51.

German soil mapping guideline, KA 5. (2005). Bodenkundliche Kartieranleitung (German soil mapping guideline): Mit 103 Tabellen und 31 Listen (5th ed.). Stuttgart: E. Schweizerbart'sche Verlagsbuchhandlung (Nägele und Obermiller).

Godwin, R. J., \& Miller, P. (2003). A review of the technologies for mapping within-field variability. Biosystems Engineering, 84(4), 393-407.

Godwin, R. J., Wood, G. A., Taylor, J. C., Knight, S. M., \& Welsh, J. P. (2003). Precision farming of cereal crops: A review of a six year experiment to develop management guidelines. Biosystems Engineering, 84(4), 375-391.

Hatfield, J. (2000). Precision agriculture and environmental quality; challenges for research and education. Iowa: U.S. Department of Agriculture's Natural Resources Conservation Service.

Heil, K., \& Schmidhalter, U. (2017). Improved evaluation of field experiments by accounting for inherent soil variability. European Journal of Agronomy, 89, 1-15.

Hengl, T. (2007). A practical guide to geostatistical mapping of environmental variables. EUR. Scientific and technical research series. Luxembourg.

Hülsbergen, K.-J. (2003). Entwicklung und Anwendung eines Bilanzierungsmodells zur Bewertung der Nachhaltigkeit landwirtschaftlicher Systeme (Development and application of an accounting model to assess the sustainability of agricultural systems). Berichte aus der Agrarwissenschaft. Aachen: Shaker.

Hülsbergen, K.-J., Maidl, F.-X., Forster, F., \& Prücklmaier, J. (2017). Minderung von Nitratausträgen in Trinkwassereinzugsgebieten durch optimiertes Stickstoffmanagement am Beispiel der Gemeinde Hohenthann (Niederbayern) mit intensiver landwirtschaftlicher Flächennutzung (Reduction of nitrate emissions in drinking water catchment areas through optimized nitrogen management) Forschungsbericht an das Bayerische Staatsministerium für Ernährung, Landwirtschaft und Forsten. Freising: Technische Universität München.

Isermann, K. (1990). Share of agriculture in nitrogen and phosphorus emissions into the surface waters of Western Europe against the background of their eutrophication. Fertilizer Research, 26(1-3), 253-269.

Kaivosoja, J., Näsi, R., Hakala, T., Viljanen, N., \& Honkavaara, E. (2019). Different remote sensing data in relative biomass determination and in precision fertilization task generation for cereal crops. In M. Salampasis \& T. Bournaris (Eds.), International conference on information and communication technologies in agriculture, food and environment (Vol. 953, pp. 164-176). Cham: Springer.

Körschens, M. (2010). Der organische Kohlenstoff im Boden (Corg) - Bedeutung, Bestimmung, Bewertung (Soil organic carbon (SOC)-Importance, determination, evaluation). Archives of Agronomy and Soil Science, 56(4), 375-392.

Křížová, K., \& Kumhálová, J. (2017). Comparison of selected remote sensing sensors for crop yield variability estimation. Agronomy Research, 15(4), 1636-1645.

Küstermann, B., Christen, O., \& Hülsbergen, K.-J. (2010). Modelling nitrogen cycles of farming systems as basis of site- and farm-specific nitrogen management. Agriculture, Ecosystems and Environment, $135(1-2), 70-80$. 
Leithold, G., Hülsbergen, K.-J., \& Brock, C. (2015). Organic matter returns to soils must be higher under organic compared to conventional farming. Journal of Plant Nutrition and Soil Science, 178(1), 4-12.

López-Lozano, R., Casterad, M. A., \& Herrero, J. (2010). Site-specific management units in a commercial maize plot delineated using very high resolution remote sensing and soil properties mapping. Computers and Electronics in Agriculture, 73(2), 219-229.

Maes, W. H., \& Steppe, K. (2019). Perspectives for remote sensing with unmanned aerial vehicles in precision agriculture. Trends in Plant Science, 24(2), 152-164.

Maidl, F.-X., Spicker, A., Weng, J., \& Hülsbergen, K.-J. (2019). Ableitung des teilflächenspezifischen Kornertrags von Getreide aus Reflexionsdaten (Derivation of the site-specific grain yield from reflection data). In A. Meyer-Aurich (Ed.), Digitalisierung in kleinstrukturierten Regionen (pp. 131-134). Bonn: Gesellschaft für Informatik.

Mauser, W., \& Bach, H. (2009). PROMET_Large scale distributed hydrological modelling to study the impact of climate change on the water flows of mountain watersheds. Journal of Hydrology, 376(3-4), 362-377.

McLellan, E. L., Cassman, K. G., Eagle, A. J., Woodbury, P. B., Sela, S., Tonitto, C., et al. (2018). The nitrogen balancing act: Tracking the environmental performance of food production. BioScience, 68(3), 194-203.

Mulla, D. J. (2013). Twenty five years of remote sensing in precision agriculture: Key advances and remaining knowledge gaps. Biosystems Engineering, 114(4), 358-371.

Noack, P. O. (2007). Ertragskartierung im Getreidebau (Yield mapping). KTBL-Heft (Vol. 70). Darmstadt: Kuratorium für Technik und Bauwesen in der Landwirtschaft e.V.

Oliver, M. A., \& Webster, R. (2015). Basic steps in geostatistics: The variogram and kriging. Springer Briefs in Agriculture. Cham: Springer.

Pahlmann, I., Böttcher, U., \& Kage, H. (2017). Developing and testing an algorithm for site-specific N fertilization of winter oilseed rape. Computers and Electronics in Agriculture, 136, 228-237.

Pan, G., Smith, P., \& Pan, W. (2009). The role of soil organic matter in maintaining the productivity and yield stability of cereals in China. Agriculture, Ecosystems and Environment, 129(1-3), 344-348.

Prücklmaier, J. (2020). Feldexperimentelle Analysen zur Ertragsbildung und Stickstoffeffizienz bei organisch-mineralischer Düngung auf heterogenen Standorten und Möglichkeiten zur Effizienzsteigerung durch computer- und sensorgestützte Düngesysteme (Field experimental analyses of yield effects and nitrogen efficiency of fertilizer application systems). Weihenstephaner Schriften Ökologischer Landbau und Pflanzenbausysteme (1st ed.). Berlin: Dr. Köster.

$\mathrm{R}$ Core Team. (2020). A language and environment for statistical computing. R Foundation for Statistical Computing. Retrieved December 18, 2020, from https://www.R-project.org/.

Roßkopf, N., Fell, H., \& Zeitz, J. (2015). Organic soils in Germany, their distribution and carbon stocks. CATENA, 133, 157-170.

Salo, T., \& Turtola, E. (2006). Nitrogen balance as an indicator of nitrogen leaching in Finland. Agriculture, Ecosystems and Environment, 113(1-4), 98-107.

Sassenrath, G. F., Schneider, J. M., Gaj, R., Grzebisz, W., \& Halloran, J. M. (2013). Nitrogen balance as an indicator of environmental impact: Toward sustainable agricultural production. Renewable Agriculture and Food Systems, 28(3), 276-289.

Segarra, J., Buchaillot, M. L., Araus, J. L., \& Kefauver, S. C. (2020). Remote sensing for precision agriculture: Sentinel-2 improved features and applications. Agronomy, 10(5), 641.

Servadio, P., Bergonzoli, S., \& Verotti, M. (2017). Delineation of management zones based on soil mechanical-chemical properties to apply variable rates of inputs throughout a field (VRA). Engineering in Agriculture, Environment and Food, 10(1), 20-30.

Shaddad, S. M. (2019). Geostatistics and proximal soil sensing for sustainable agriculture. In A. M. Negm \& M. Abu-hashim (Eds.), Sustainability of agricultural environment in Egypt: Part I (Vol. 76, pp. 255-271). Cham: Springer.

Sieling, K., \& Kage, H. (2006). N balance as an indicator of N leaching in an oilseed rape-winter wheatwinter barley rotation. Agriculture, Ecosystems and Environment, 115(1-4), 261-269.

Spicker, A. (2016). Entwicklung von Verfahren der teilflächenspezifischen Stickstoffdüngung zu Wintergerste (Hordeum vulgare L.) und Winterraps (Brassica napus L.) auf Grundlage reflexionsoptischer Messungen (Development of sensor-based nitrogen fertilization systems for oilseed rape (Brassica napus L.) and winter wheat (Hordeum vulgare L.)). Weihenstephaner Schriften Ökologischer Landbau und Pflanzenbausysteme, Band 5 (1st ed.). Berlin: Dr. Köster.

Stamatiadis, S., Schepers, J. S., Evangelou, E., Tsadilas, C., Glampedakis, A., Glampedakis, M., et al. (2018). Variable-rate nitrogen fertilization of winter wheat under high spatial resolution. Precision Agriculture, 19(3), 570-587. 
TEC5. (2010). Mobile Spectroscopy, Version 2.13. tec5 AG Oberursel. Retrieved December 19, 2020, from https://www.tec5.com/en/our-solutions/mobile-spectroscopy.

Thompson, S. K. (2002). On sampling and experiments. Environmetrics, 13(5-6), 429-436.

Tiessen, H., Cuevas, E., \& Chacon, P. (1994). The role of soil organic matter in sustaining soil fertility. Nature, 371(6500), 783-785.

van der Ploeg, R. R., Ringe, H., Machulla, G., \& Hermsmeyer, D. (1997). Postwar nitrogen use efficiency in West German agriculture and groundwater quality. Journal of Environment Quality, 26(5), 1203.

Walter, A., Finger, R., Huber, R., \& Buchmann, N. (2017). Opinion: Smart farming is key to developing sustainable agriculture. Proceedings of the National Academy of Sciences of the United States of America, 114(24), 6148-6150.

Whelan, B. (2018). Site-specific crop management. In A. McBratney, B. Minasny, \& U. Stockmann (Eds.), Pedometrics (Vol. 42, pp. 597-622). Cham: Springer.

Wiesmeier, M., Urbanski, L., Hobley, E., Lang, B., von Lützow, M., Marin-Spiotta, E., et al. (2019). Soil organic carbon storage as a key function of soils-A review of drivers and indicators at various scales. Geoderma, 333, 149-162.

Wintersteiger. (2018). Laboratory thresher. Retrieved September 25, 2020, from https://www.wintersteiger. com/us/Plant-Breeding-and-Research/Products/Product-Range/Stationary-thresher.

Publisher's note Springer Nature remains neutral with regard to jurisdictional claims in published maps and institutional affiliations.

\section{Authors and Affiliations}

\section{Martin Mittermayer ${ }^{1} \mathbb{D} \cdot$ August Gilg $^{2} \cdot$ Franz-Xaver Maidl $^{1} \cdot$ Ludwig Nätscher $^{1}$. Kurt-Jürgen Hülsbergen ${ }^{1}$}

August Gilg

august.gilg@online.de

Franz-Xaver Maidl

maidl@wzw.tum.de

Ludwig Nätscher

ludwig.naetscher@tum.de

Kurt-Jürgen Hülsbergen

huelsbergen@wzw.tum.de

1 Chair of Organic Agriculture and Agronomy, Technische Universität München, Liesel - Beckmann

- Straße 2, 85354 Freising, Germany

2 Pattern Recognition and Software Engineering, Hochschule Weihenstephan-Triesdorf, Vöttinger Straße 27, 85354 Freising, Germany 